\title{
POTENSI ANTIOKSIDAN EKSTRAK ETANOL DAUN SAMBUNG NYAWA (Gynura procumbens) TERENKAPSULASI MALTODEXTRIN DAN PENGARUHNYA TERHADAP KADAR MDA DARAH TIKUS WISTAR (Rattus novergicus) JANTAN YANG DIINDUKSI $\mathrm{CCl}_{4}$
}

\author{
Sulfiyana H. Ambo Lau, Elly Wahyudin, Subehan Lallo \\ Fakultas Farmasi, Universitas Hasanuddin, Makassar
}

\section{Kata Kunci :}

Gynura procumbens, enkapsulasi, $\mathrm{CCl}_{4}, \mathrm{MDA}$, flavonoid total, polifenol total

\section{Masuk 05-11-2018 \\ Revisi $\quad 30-12-2018$}

Diterima 04-01-2019

\section{Korespondensi}

\section{Elly Wahyudin}

ellywahyudins@gmail.com

Copyright

(C) 2018 Majalah Farmasi

Farmakologi Fakultas

Farmasi · Makassar

Diterbitkan tanggal 04-01-2019

Dapat Diakses Daring Pada:

\begin{abstract}
ABSTRAK
$\mathrm{CCl}_{4}$ merupakan senyawa yang dapat mengakibatkan toksisitas. Daun sambung nyawa (Gynura procumbens) merupakan salah satu tanaman yang memiliki senyawa antioksidan yang memiliki banyak berpotensi dalam bidang pengobatan. Tujuan dari penelitian ini adalah untuk mengetahui potensi antioksidan ekstrak etanol daun sambung nyawa (Gynura procumbens) yang dienkapsulasi maltodextrin terhadap kadar MDA darah tikus Wistar (Rattus novergicus) jantan yang diinduksi $\mathrm{CCl}_{4}$. Penelitian ini menggunakan 20 ekor tikus Wistar jantan yang terbagi dalam 4 kelompok yaitu kelompok 1 (kontrol sehat), kelompok $2\left(\mathrm{CCl}_{4}\right)$, kelompok $3\left(\mathrm{CCl}_{4}+\right.$ ekstrak $\left.150 \mathrm{mg} / \mathrm{kgBB}\right)$, dan kelompok $4\left(\mathrm{CCl}_{4}+\right.$ ekstrak $300 \mathrm{mg} / \mathrm{kgBB}$ ). Kadar MDA diperiksa sebelum dan setelah 14 hari perlakuan. Hasil pengujian dimana ekstrak etanol daun sambung nyawa mengandung senyawa alkaloid, fenolik, flavonoid, saponin, steroid, tanin, dan terpenoid, serta kadar flavonoid total dan polifenol totalnya masing-masing yaitu $0,482 \%$ dan 2,12 \%. Pengujian awal rata-rata kadar MDA tidak berbeda signifikan. Peningkatan kadar MDA yang signifikan $(\mathrm{p}<0,05)$ terjadi setelah perlakuan hari 14 . Pemberian ekstrak dosis $150 \mathrm{mg} / \mathrm{kgBB}$ dan $300 \mathrm{mg} / \mathrm{kgBB}$ mencegah peningkatan kadar MDA secara signifikan, namun dosis $300 \mathrm{mg} / \mathrm{kgBB}$ paling efektif menghambat peningkatan kadar MDA. Kesimpulannya bahwa ekstrak etanol daun sambung nyawa terenkapsulasi maltodextrin mampu mencegah peningkatan aktivitas peroksidasi lipid MDA paling baik pada dosis $300 \mathrm{mg} / \mathrm{kgBB}$.
\end{abstract}

\section{PENDAHULUAN}

Salah satu bahan kimia dengan model cedera terbaik yang diproduksi di hati adalah dengan $\mathrm{CCI}_{4} . \mathrm{CCl}_{4}$ digunakan sebagai agen hepatotoksik pada penelitian hewan untuk mempelajari tindakan hepatokuratif tanaman dan senyawa lainnya (1). Hati bukan satu-satunya organ sasaran $\mathrm{CCl}_{4}$ tapi juga mempengaruhi beberapa organ tubuh lainnya seperti pada paru-paru, hati, testis, ginjal dan juga otak (2).

Sambung nyawa (Gynura procumbens (Lour.) Merr.) Family Asteraceae adalah tanaman obat yang biasa ditemukan di negara-negara Asia tropis seperti Indonesia, China, Thailand, Malaysia, dan Vietnam. Secara tradisional, banyak digunakan di berbagai negara untuk pengobatan berbagai macam penyakit untuk kesehatan (3). Sambung nyawa mengandung senyawa kimia, seperti flavonoid, sterol tak jenuh, triterpenoid, polifenol, saponin, steroid, asam klorogenat, asam kafeat, asam vanilat, asam para kumarat, asam para hidroksi benzoat, dan minyak atsiri (4). Khasiat daun sambung nyawa (Gynura procumbens) sudah diteliti sejak ratusan tahun yang lalu. Daun sambung nyawa berkhasiat untuk obat liver, ambeien, maag, kolesterol tinggi, tumor, kencing manis, dan obat penurun panas. Daun sambung nyawa juga dipercaya berkhasiat sebagai obat dalam terapi penyakit ginjal, disentri, infeksi kerongkongan, menghentikan perdarahan, melancarkan haid, obat gigitan binatang berbisa, dan pembengkakan (5).

Ekstrak etanol dari G. procumbens menghambat ekspresi MMP-1 dan MMP-9 yang disebabkan oleh iradiasi UV-B melalui penghambatan pelepasan mediator sitokin pro-inflamasi dan produksi ROS (6). Ekstrak etanol sambung nyawa berkorelasi positif terhadap aktivitas antiradikalnya (7). Ekstrak etanol G. procumbens dan salah satu bahan aktifnya, asam klorogenat, dapat dikembangkan sebagai agen efektif potensial untuk cedera hati diakibatkan oleh pemberian etanol (8).

Enkapsulasi menggambarkan proses yang berbeda untuk menutupi senyawa aktif dengan bahan dinding pelindung dan dapat digunakan untuk mengobati rasa sehingga memberikan beberapa tingkat perlindungan terhadap penguapan, reaksi, atau migrasi dalam makanan. Enkapsulasi telah dicoba dan dikomersilkan menggunakan banyak metode yang berbeda salah satunya Freeze drying (9). Maltodekstrin terbukti cocok untuk digunakan dalam persiapan enkapsulasi dan menggunakan metode pengeringan beku lebih baik dalam hal kelembaban, aktivitas air, lemak, gula total, warna, bulk density, tingkat benjolan, mikrobiologi photomicrograph scanning elektron dan atribut sensorik, termasuk aroma, penampilan dan warna (10). 


\section{METODE PENELITIAN}

\section{Rancangan Penelitian}

Penelitian yang telah dilakukan adalah jenis penelitian eksperimental laboratorium terhadap hewan coba, Rancangan penelitian menggunakan rancangan eksperimental Pretest-Postest Control Group Design.

\section{Lokasi dan Waktu}

Penelitian telah dilakukan pada bulan Mei hingga Agustus 2018 di Laboratorium Fitokimia, Farmasi klinik, dan Laboratorium Biofarmasi Fakultas Farmasi serta Laboratorium Biofarmaka Pusat Kegiatan Penelitian, Universitas Hasanuddin, Makassar.

\section{Bahan dan Alat}

\section{Bahan}

Bahan yang akan digunakan pada penelitian ini adalah, air suling, alkohol 70\%, aluminium foil, asam tiobarbiturat (TBA), asam trikloroasetat (TCA), $\mathrm{CCl}_{4}$, daun sambung nyawa (Gynura procumbens) (Belopa, Luwuk, Sulawesi Selatan, tidak diketahui umur dan keadaan pohon induknya, di ambil April 2018), etanol 70\%, eter, kapas, Handscoon, kapas, maltodextrin, masker, pakan standar untuk hewan coba, pereaksi uji identifikasi, pereaksi uji total flavonoid, pereaksi uji total polifenol, phosphate buffer saline (PBS), serbuk kayu, tikus putih jantan (Rattus novergicus) (Wistar, 2-4 bulan, 150$250 \mathrm{~g}$ ), tissue, dan TMP.

\section{Alat}

Alat yang akan digunakan pada penelitian ini adalah alat bedah, alat-alat gelas di laboratorium (Pyrex), batang pengaduk, buku (alat/media pencatat data), cawan petri plastik, disposable syringes, freeze dryer, kamera, kandang pemeliharaan tikus, kanula, kertas saring Wattman no. 1, mikropipet, oven, pipet kapiler, pipet tetes panjang, pipet tetes pendek, pisau, rotary evaporator, sekam, sonde lambung, sudip, spektrofotometer Uv-Vis (Shimadu), spoit, tabung effendorf, timbangan analitik, timbangan hewan, vacutainer, wadah air minum hewan, dan vial.

\section{Hewan}

Hewan yang digunakan dalam penelitian ini adalah 20 ekor tikus Wistar (Rattus novergicus) jantan yang sehat dengan bobot 150-250 g.

\section{Prosedur Kerja}

Proses Pembuatan Sampel Ekstrak Daun Sambung Nyawa

\section{Determinasi Tumbuhan}

Determinasi tumbuhan dilakukan di Herbarium Bogoriensis LIPI Bogor dan Laboratorium Botani Jurusan Biologi FMIPA UNM, Makassar.

\section{Persiapan Sampel daun Sambung Nyawa}

Sampel daun sambung nyawa sebanyak $2 \mathrm{~kg}$ sampel dalam bentuk segar, dibersihkan dari kotoran yang menempel (sortasi basah), dicuci dengan air mengalir, dipotong kecilkecil, disortasi kering, dan dikeringkan. Setelah kering dan rapuh, selanjutnya dihaluskan, diayak (mesh 40), ditimbang bobotnya, kemudian dimasukkan ke dalam wadah. Kemudian dimaserasi. Rendamen dari ekstrak dihitung dengan rumus:

$$
(\%) \text { Rendamen }=\frac{\text { Berat ekstrak }}{\text { Berat simplisia }} \times 100 \%
$$

Pembuatan Ekstrak daun Sambung Nyawa

Sebanyak 200 g simplisia daun sambung nyawa dimaserasi menggunakan pelarut etanol $70 \%$ sebanyak 1,5 L (11). Selama 3 hari dimaserasi dengan sesekali pengadukkan. Hari ketiga, dilakukan penyaringan dengan kertas saring Wattman no. 1 dan ampasnya diremaserasi sebanyak 3 kali. Hasil saringan ditampung dan dipekatkan menggunakan rotary evaporator sehingga diperoleh ekstrak etanol yang pekat.

Pembuatan Ekstrak Terenkapsulasi

Ekstrak etanol yang telah dipekatkan ditambahkan dengan $10 \%$ maltodekstrin lalu dikeringkan dengan menggunakan freeze dryer hingga menjadi serbuk sambung nyawa terenkapsulasi maltodekstrin.

\section{Analisis Kualitatif Komponen Senyawa}

\section{Alkaloid}

Ekstrak etanol daun sambung nyawa terenkapsulasi dicampur dengan $5 \mathrm{ml}$ kloroform dan $5 \mathrm{ml}$ amoniak lalu dipanaskan, dikocok dan disaring. Sebanyak 5 tetes asam sulfat $2 \mathrm{~N}$ ditambahkan pada masing-masing filtrat, lalu dikocok dan didiamkan. Bagian atas dari masing-masing filtrat diambil dan diuji dengan pereaksi Dragendorf (endapan jingga), Mayer (endapan putih), dan Wagner (endapan coklat) (12).

\section{Fenolik}

Ekstrak etanol daun sambung nyawa terenkapsulasi direaksikan dengan larutan $\mathrm{FeCl}_{3}$ 1\%. Hasil ditunjukkan dengan terbentuknya warna hijau, merah, ungu, biru tua, biru, bru kehitaman, atau hijau kehitaman (12).

\section{Flavonoid}

Ekstrak etanol daun sambung nyawa terenkapsulasi sebanyak $\pm 1 \mathrm{ml}$ dicampurkan dengan $3 \mathrm{ml}$ metanol, lalu dikocok, dipanaskan, dikocok lagi kemudian disaring. Filtrat yang diperoleh ditambahkan serbuk $\mathrm{Mg} 0,1 \mathrm{~g}$ dan $\mathrm{HCl}$ pekat 2 tetes. Hasil ditunjukkan dengan terbentuknya endapan merah (flavon), endapan merah tua (flavonol/flavonon), dan endapan hijau (senyawa glikosisa/aglikon) (12).

\section{Saponin}

Sebanyak 0,5 g ekstrak etanol daun sambung nyawa terenkapsulasi dimasukkan ke dalam tabung reaksi, ditambahkan $10 \mathrm{ml}$ air panas, didinginkan kemudian dikocok selama 10 detik. Hasil jika terbentuk busa setinggi 1 sampai $10 \mathrm{~cm}$ yang stabil tidak kurang dari 10 menit dan tidak hilang dengan penambahan 1 tetes $\mathrm{HCl} 2 \mathrm{~N}$ (12).

Steroid

Ekstrak etanol daun sambung nyawa terenkapsulasi sebanyak $1 \mathrm{ml}$ dicampur dengan $3 \mathrm{ml}$ kloroform atau metanol, lalu ditambahkan $2 \mathrm{ml}$ asam sulfat pekat dan $2 \mathrm{ml}$ asam asetat anhidrat. Hasil perubahan warna dari ungu ke biru atau hijau (12).

Tanin

Sebanyak 0,5 g Ekstrak etanol daun sambung nyawa terenkapsulasi disari dengan $10 \mathrm{ml}$ aquades kemudian disaring, filtratnya diencerkan dengan air sampai tidak berwarna. Larutan diambil sebanyak $2 \mathrm{ml}$ dan ditambahkan 2 tetes $\mathrm{FeCl}_{3}$ 1\%. Jika terjadi warna hijau, biru atau kehitaman menunjukkan adanya tanin (12).

\section{Terpenoid}

Ekstrak etanol daun sambung nyawa terenkapsulasi direaksikan dengan $0,5 \mathrm{ml}$ etanol, $0,5 \mathrm{ml}$ asam asetat anhidrat, dan $2 \mathrm{ml}$ asam sulfat pekat melalui dinding tabung. Hasil ditunjukkan dengan terbentuk warna hijau dan biru (triterpenoid), merah atau ungu (steroid) dan kecoklatan (terpenoid) (12). 


\section{Analisis Kuantitatif Flavonoid Total}

Pembuatan Larutan $\mathrm{AlCl}_{3}$

Ditimbang sebanyak 5 gram $\mathrm{AlCl}_{3}$ kemudian dilarutkan dengan air suling dan dicukupkan hingga $50 \mathrm{~mL}$.

Pembuatan Larutan $\mathrm{CH}_{3} \mathrm{COONa} 1 \mathrm{M}$

Ditimbang sebanyak 4,1 gram $\mathrm{CH}_{3} \mathrm{COONa}$ kemudian dilarutkan dengan air suling hingga $50 \mathrm{~mL}$.

\section{Pembuatan Larutan Kuersetin}

Larutan standar kuersetin 1000 ppm dibuat dengan menimbang $10 \mathrm{mg}$ kuersetin lalu dilarutkan dengan air suling hingga volume $10 \mathrm{ml}$, kemudian dibuat pengenceran 100 ppm dengan cara dipipet $1 \mathrm{ml}$ lalu dicukupkan dengan air suling hingga volume $10 \mathrm{ml}$.

\section{Penentuan Panjang Gelombang Maksimal ( $\lambda_{\text {maks }}$ )}

Larutan kuersetin dipipet $1 \mathrm{~mL}$ ditambahkan pereaksi yang terdiri dari $0,5 \mathrm{~mL} \mathrm{AlCl}_{3} 10 \%, 0,5 \mathrm{~mL} \mathrm{CH}_{3} \mathrm{COONa}$ dan dicukupkan volumenya hingga $5 \mathrm{~mL}$ dengan aquadest. Larutan dihomogen dan didiamkan pada suhu ruangan selama 30 menit. Selanjutnya larutan diukur serapannya pada alat spektrofotometer UV-Vis 400-500 nm. Absorbansi maksimum yang diperoleh pada panjang gelombang $424 \mathrm{~nm}$ merupakan panjang gelombang maksimum kuersetin.

\section{Pembuatan Kurva Baku Larutan Standar Kuersetin}

Pembuatan kurva baku kuersetin dengan varian konsentrasi 1; 2; 4; 8 dan 16 ppm dimasukkan dalam tabung masingmasing dipipet $1 \mathrm{~mL}$ kemudian ditambahkan $0,5 \mathrm{~mL} \mathrm{AlCl}_{3}, 0,5$ $\mathrm{mL} \mathrm{CH} 3 \mathrm{COONa}$ dan dicukupkan volumenya dengan aquadest hingga $5 \mathrm{~mL}$. Selanjutnya didiamkan selama 30 menit pada suhu ruangan, kemudian diukur absorbansi pada panjang gelombang serapan maksimum $424 \mathrm{~nm}$. Dibuat kurva kalibrasinya yang merupakan hubungan antara konsentrasi kuersetin dan absorbansi.

Pengukuran Kadar Flavonoid Total dari Ekstrak Daun Sambung Nyawa (Gynura Procumbens) Terenkapsulasi

Dipipet sebanyak $1 \mathrm{~mL}$ larutan ekstrak etanol daun sambung nyawa terenkapsulasi, kemudian ditambahkan $0,5 \mathrm{~mL} \mathrm{AlCl}_{3}$ $10 \%, 0,5 \mathrm{~mL} \mathrm{CH}_{3} \mathrm{COONa}$ dan dicukupkan volumenya hingga 5 $\mathrm{mL}$ dengan etanol 96\%. Selanjutnya didiamkan selama 30 menit pada suhu ruangan, kemudian diukur serapannya dengan spektrofotometer UV-Vis pada panjang gelombang serapan maksimum $424 \mathrm{~nm}$. Dilakukan 3 kali pengulangan dan dihitung kadar senyawa flavonoid yang diperoleh. Dilakukan hal yang sama untuk larutan blanko (18).

\section{Analisis Kuantitatif Polifenol Total}

\section{Pembuatan Larutan $\mathrm{NaOH}$}

Timbang $\mathrm{NaOH}$ sebanyak 40 gram kemudian larutkan dengan air suling $200 \mathrm{ml}$. Panaskan air suling, setelah itu didinginkan lalu masukkan $\mathrm{NaOH}$ ke dalam labu takar 1000 ml, kemudian cukupkan hingga batas tanda.

Pembuatan Larutan Asam Galat

Sebanyak $50 \mathrm{mg}$ asam galat dilarutkan dalam 0,5 ml etanol p.a kemudian diencerkan dengan air suling sampai volume $100 \mathrm{ml}$.

\section{Penentuan Panjang Gelombang Maksimal ( $\left.\boldsymbol{\lambda}_{\text {maks }}\right)$}

Sebanyak $1 \mathrm{ml}$ larutan asam galat ditambahkan 2,5 $\mathrm{ml}$ Folin ciocalteu dan $2 \mathrm{ml} \mathrm{NaOH} 1 \mathrm{~N}$, lalu dicukupkan dengan air suling hingga batas tanda, kemudian diinkubasi selama 1 jam. Serapan diukur dengan spektrofotometer pada panjang gelombang $\lambda_{\text {maks }} 648 \mathrm{~nm}$.

\section{Pembuatan Kurva Baku Larutan Standar Asam galat}

Pembuatan kurva baku asam galat dengan variasi konsentrasi 1,5; 3; 7; 10 dan 15 ppm dimasukkan dalam tabung masing-masing $1 \mathrm{ml}$ larutan asam galat ditambahkan pereaksi 2,5 ml Folin ciocalteu dan $2 \mathrm{ml} \mathrm{NaOH} 1 \mathrm{~N}$ dan dicukupkan dengan air suling hingga batas tanda. Kemudian diinkubasi selama 1 jam, serapan diukur dengan spektrofotometri pada panjang gelombang maksimum $\lambda_{\text {maks }}$ $648 \mathrm{~nm}$. Dibuat kurva kalibrasinya.

Pengukuran Kadar Flavonoid Total dari Ekstrak Daun Sambung Nyawa (Gynura Procumbens) Terenkapsulasi

Sampel ditimbang 0,01 g dilarutkan dalam metanol p.a dan dimasukkan dalam labu tentukur $10 \mathrm{ml}$, diambil $0,5 \mathrm{ml}$ dimasukkan ke dalam labu tentukur $5 \mathrm{ml}$, ditambahkan 2,5 ml Folin ciocalteu dan $2 \mathrm{ml} \mathrm{NaOH} 1 \mathrm{~N}$. Diinkubasi selama 1 jam, serapan diukur dengan spektrofotometri pada panjang gelombang maksimum $\lambda_{\text {maks }} 648 \mathrm{~nm}$.

\section{Penyiapan Sedian Uji}

\section{Perhitungan dosis dan pembuatan $\mathrm{CCl}_{4}$}

Dosis $\mathrm{CCl}_{4}$ yang diberikan $10 \mathrm{ml} / \mathrm{kgBB}\left(1 \% \mathrm{v} / \mathrm{v} \mathrm{CCl} \mathrm{Cl}_{4}\right.$ dalam minyak) $0,5 \mathrm{ml} \mathrm{CCl}_{4}$ dalam $50 \mathrm{ml}$ minyak. Volume $1 \mathrm{ml}$ dosis $\mathrm{CCl}_{4} 0,01 \mathrm{ml}$.

\section{Pembuatan Larutan Uji Daun Sambung Nyawa Terenkapsulasi}

Dosis daun sambung nyawa terenkapsulasi maltodextrin yang akan digunakan adalah $150 \mathrm{mg} / \mathrm{kgBB} /$ hari, dan 300 $\mathrm{mg} / \mathrm{kgBB} /$ hari. Larutan ekstrak daun sambung nyawa dibuat dalam 2 variasi dosis:

Dosis $150 \mathrm{mg} / \mathrm{kgBB}$ dibuat dengan menimbang ekstrak sebanyak 0,75 g kemudian dilarutkan dengan aquadest sebanyak $50 \mathrm{ml}$, sehingga dalam larutan $1 \mathrm{ml}$ mengandung 15 mg ekstrak.

Dosis $300 \mathrm{mg} / \mathrm{kgBB}$ dibuat dengan menimbang ekstrak sebanyak 1,5 g kemudian dilarutkan dengan aquadest sebanyak $50 \mathrm{ml}$, sehingga dalam larutan $1 \mathrm{ml}$ mengandung 30 mg ekstrak.

\section{Instrumen Pengumpulan Data}

\section{Penanganan Hewan Uji}

Sebanyak 20 ekor tikus Wistar (Rattus novergicus) jantan dibagi menjadi 4 kelompok perlakuan. Setiap kelompok yang terdiri dari 5 ekor tikus (Rattus novergicus) jantan diberikan perlakuan selama 14 hari. Adapun 4 kelompok tersebut yaitu:

Kelompok 1 : Kontrol sehat (Diberikan air suling)

Kelompok 2 : Kontrol negatif (Diberikan penginduksi $\mathrm{CCl}_{4}$ )

Kelompok 3 : Ekstrak daun sambung nyawa terenkapsulasi dosis $150 \mathrm{mg} / \mathrm{kgBB} /$ hari $+\mathrm{CCl}_{4}$

Kelompok 4 : Ekstrak daun sambung nyawa terenkapsulasi dosis $300 \mathrm{mg} / \mathrm{kgBB} /$ hari $+\mathrm{CCl}_{4}$

Dosis $\mathrm{CCl}_{4}$ yang digunakan $10 \mathrm{ml} / \mathrm{kgBB}(1 \mathrm{ml} / 100 \mathrm{gBB})$. Tikus kelompok 3 dan 4 pada hari ke-6 setelah diberikan suspensi ekstrak daun sambung nyawa terenkapsulasi, 3 jam kemudian diberikan $\mathrm{CCl}_{4}$. Sebelum perlakuan tikus dipuasakan selama 8 jam dan ditimbang bobotnya terlebih dahulu. Pemberian ekstrak daun sambung nyawa diberikan secara oral menggunakan alat berupa kanula khusus tikus. Dosis yang diberikan sesuai dengan bobot hewan uji.

\section{Pemeriksaan MDA}

\section{Pengukuran Kurva Baku}

Larutan baku yang digunakan dalam mengukur kadar peroksidasi lipid adalah baku diagnostik MDA yaitu 1,1,3,3tetrametoksipropana (TMP). Larutan baku dibuat dengan menggunakan larutan stock $1 \mathrm{ml}$ TMP yang dilarutkan dalam 10 ml PBS (Phosphate buffer saline). Kemudian dibuat 8 
variasi pengenceran yaitu 0,$05 ; 0,1 ; 0,15 ; 0,2 ; 0,25 ; 0,3 ; 0,35$; dan 0,4 ppm.

\section{Pemeriksaan MDA}

Salah satu cara mengetahui aktivitas peroksidasi lipid adalah mengukur kadar malondyaldehid (MDA) menggunakan metode thiobarbituric acid reactive substance (TBARS). Sampel serum darah dipipet sebanyak 0,5 ml kemudian ditambahkan $1 \mathrm{ml}$ campuran TBA 1\% dan TCA 1\% ke dalam tabung dan dipanaskan di dalam tangas air pada suhu $100^{\circ} \mathrm{C}$ selama 40 menit dan didinginkan pada suhu kamar. Disentrifugasi kembali dengan kecepatan 3000 rpm selama 10 menit, kemudian dipipet supernatannya dan diukur kadar MDA dengan spektrofotometer UV-Vis pada panjang gelombang $535 \mathrm{~nm}$.

\section{Pengolahan dan Analisis Data}

Data yang diperoleh kemudian diolah dengan program komputer SPSS for window. Proses analisis data kadar MDA darah diperoleh distribusi normal sehingga dianalisis dengan One Way Anova dan dilanjutkan dengan Post Hoc Tukey.

\section{HASIL DAN PEMBAHASAN}

Daun sambung nyawa yang diekstraksi dari 2000 g sampel segar diperoleh persen rendamen sebesar 5,56\% (25 g). Dari penelitian dengan pelarut air 1:30 (v/w) pada ukuran partikel B $(<100 \mu \mathrm{m})$ memberikan hasil rendamen lebih tinggi $(25,83 \% \pm 6,79)$ (13). Pada penelitian dengan 500 gram sampel kering daun sambung nyawa (Gynura procumbens (Lour.) Merr.) didapatkan hasil ekstrak kental etanol sebanyak 50,325 gram dengan persen rendemen sebanyak $10,065 \%$ (14). Ada banyak hal yang dapat mempengaruhi hasil rendamen dimana pelarut, ukuran partikel, perbandingan pelarut dan sampel, pemilihan metode ekstraksi, lokasi tumbuh dan bagian tanaman yang digunakan juga berperan penting untuk menghasilkan jumlah rendamen yang maksimal.

Ekstrak etanol daun sambung nyawa yang telah dienkapsulasi diidentifikasi golongan senyawa kimianya. Identifikasi golongan senyawa kimia memiliki tujuan untuk mengetahui kandungan golongan senyawa kimia yang terdapat pada ekstrak. Hasil identifikasi tersebut dapat dijadikan acuan untuk mengetahui golongan senyawa kimia yang memberikan kemampuan dalam hal memproteksi hati dan ginjal. Berdasarkan uji identifikasi komponen senyawa kimia yang telah dilakukan dihasilkan bahwa ekstrak etanol $70 \%$ daun sambung nyawa terenkasulasi positif mengandung alkaloid, fenolik, flavonoid, saponin, steroid, tanin, dan terpenoid.

Hasil pengujian alkaloid menunjukkan bahwa ekstrak etanol daun sambung nyawa positif mengandung alkaloid hal ini dibuktikan dengan ada terbentuknya endapan pada larutan yang terdapat dalam tabung reaksi setelah ditetesi pereaksi dragendorff, mayer, dan wagner. Reaksi untuk pereaksi dragendorff terbentuk endapan jingga, reaksi dengan pereaksi mayer terbentuk endapan putih, dan untuk pereaksi wagner terbentuk endapan coklat.

Hasil pengujian fenolik hasilnya positif dtunjukkan dengan adanya perubahan warna hijau menjadi warna biru, akibat adanya reaksi dengan besi (III) klorida. Pereaksi $\mathrm{FeCI}_{3}$; digunakan secara luas untuk mengidentifikasi senyawa fenol termasuk tannin. Oleh sebab itu dapat terjadi kemungkinan bahwa hasil positif juga dapat diberikan oleh senyawa fenolik lain dalam sampel (15).

Hasil pengujian untuk mengidentifikasi adanya senyawa flavanoid dengan menggunakan serbuk $\mathrm{Mg}$ dan $\mathrm{HCl}$ pekat, diperoleh perubahan warna larutan menjadi warna merah bata sehingga sampel dinyatakan positif mengandung flavanoid glikosida atau flavanoid aglikon. Penambahan asam klorida dan magnesium menyebabkan tereduksinya senyawa flavonoid sehingga menghasilkan perubahan warna (16).

Hasil pengujian saponin hasilnya positif ditunjukkan dengan terbentuknya busa yang dapat bertahan selama 1 menit dengan ketinggian $1 \mathrm{~cm}$. Busa yang ditimbulkan karena adanya kombinasi struktur senyawa penyusunnya yaitu rantai sapogenin non polar dan rantai samping polar yang larut dalam air, sehingga busa yang ditimbulkan dapat bertahan selama 10 menit dengan ketinggian 1-3 cm (17).

Hasil pengujian steroid hasil positif ditunjukkan terjadi perubahan warna hijau. Hasil pengujian tanin hasil positif ditunjukkan dengan terjadinya perubahan warna hijau menjadi biru kehitaman. saat penambahannya $\mathrm{FeCl}_{3}$ diperkirakan $\mathrm{FeCl}_{3}$ bereaksi dengan salah satu gugus hidroksil yang ada pada senyawa tannin. Hasil reaksi itulah yang akhirnya menimbulkan warna (15).

Hasil pengujian terpenoid menggunakan pereaksi liebermanburchard hasil positif ditandai dengan terbentuknya cincin coklat pada batas larutan. Perubahan warna yang terjadi akibat oksidasi pada golongan senyawa terpenoid melalui peningkatan ikatan ganda terkonjugasi (18)

Analisis kuantitatif flavonoid total dilakukan dengan pembuatan larutan standar kuersetin dan larutan uji ekstrak dengan dan tanpa penambahan aluminium klorida (blanko). Penambahan aluminium klorida akan membentuk kompleks asam yang stabil dengan gugus $\mathrm{C}-4$ (gugus keto), lalu dengan C-3 atau C-5 (gugus hidroksil) dari flavon dan flavonol. Selain itu, aluminium klorida membentuk kompleks asam yang labil dengan gugus orto dihidroksil dalam cincin A atau B dari flavonoid (19). Dengan demikian penambahan aluminium klorida dapat menggeser posisi absorbansi maksimum flavonoid, sedangkan penambahan $\mathrm{CH}_{3} \mathrm{COONa}$ juga menyebabkan pergeseran absorbansi maksimum yang terjadi karena adanya ionisasi pada gugus hidroksil atom C-7 dan adanya oksigenasi pada C-6 dan C-8 (20). Panjang gelombang maksimum yang dihasilkan dari larutan standar kuersetin yaitu $424 \mathrm{~nm}$, yang digunakan untuk mengukur serapan larutan standar kuersetin dan sampel ekstrak etanol daun sambung nyawa terenkapsulasi. Berdasarkan hasil pengukuran kurva baku, maka diperoleh persamaan regresi linier yaitu $y=0,082 x+0,009$ dengan nilai koefisien korelasi $\mathrm{R}^{2}=0,997$. Nilai $\mathrm{R}$ yang mendekati 1 menunjukkan kurva kalibrasi linier dan terdapat hubungan antara konsentrasi larutan kuersetin dengan nilai serapan (absorbansi). Setelah itu dilakukan pengukuran kadar flavonoid total ekstrak etanol daun sambung nyawa terenkapsulasi (Tabel 1).

\begin{tabular}{|c|c|c|c|c|}
\hline $\begin{array}{c}\text { Persamaan linier } \\
\text { kurva baku }\end{array}$ & $\begin{array}{c}\text { Absorbansi } \\
\text { sampel }\end{array}$ & $\begin{array}{l}\text { Absorban } \\
\text { si blanko }\end{array}$ & $\begin{array}{c}\text { Nilai } x \\
(\mu \mathrm{g} / \mathrm{ml})\end{array}$ & $\begin{array}{l}\text { Flavonoid } \\
\text { total (\%) }\end{array}$ \\
\hline & 0,378 & 0 & 4,5 & 0,45 \\
\hline$y=0,082 x+0,009$ & 0,404 & 0 & 4,82 & 0,482 \\
\hline \multirow{3}{*}{$R^{2}=0,997$} & 0,389 & 0 & 4,64 & 0,464 \\
\hline & & & Rata-rata & 0,465 \\
\hline & & & SD & 0,013 \\
\hline
\end{tabular}

Hasil perhitungan kadar flavonoid total ekstrak etanol daun sambung nyawa dengan pelarut etanol $70 \%$ diperoleh kadar flavonoid total sebesar 0,465 \% b/b QE. Penelitian sebelumnya yang dilakukan oleh Afandi et al (21) memperoleh nilai flavonoid total ekstrak etanol daun sambung nyawa tertinggi sebesar 219,35 \pm 1,17 mg ekstrak $\mathrm{QE} / g$, dimana pelarut yg digunakan metanol, etanol dan air. Selanjutnya penelitian yang dilakukan oleh Algariri et al (22) 
kadar flavonoid total ekstrak etanol $75 \%$ daun sambung nyawa sebesar 26,26 mg QE/g.

Analisis kuantitatif polifenol total, panjang gelombang maksimum yang dihasilkan dari larutan standar asam galat yaitu $648 \mathrm{~nm}$, yang digunakan untuk mengukur serapan larutan standar asam galat dan sampel ekstrak etanol daun sambung nyawa terenkapsulasi. Berdasarkan hasil pengukuran kurva baku, maka diperoleh persamaan regresi linier yaitu $\mathrm{y}=0,077 \mathrm{x}-0,069$ dengan nilai koefisien korelasi $\mathrm{R}^{2}=0,996$. Nilai $\mathrm{R}$ yang mendekati 1 menunjukkan kurva kalibrasi linier dan terdapat hubungan antara konsentrasi larutan asam galat dengan nilai serapan (absorbansi). Setelah itu dilakukan pengukuran kadar polifenol total ekstrak etanol daun sambung nyawa terenkapsulasi (Tabel 2).

Tabel 2. Hasil pengukuran kadar polifenol total pada ekstrak etanol daun Sambung Nyawa terenkapsulasi

\begin{tabular}{ccccc}
\hline $\begin{array}{c}\text { Persamaan } \\
\text { linier kurva } \\
\text { baku }\end{array}$ & $\begin{array}{c}\text { Absorbansi } \\
\text { sampel }\end{array}$ & $\begin{array}{c}\text { Absorbansi } \\
\text { blanko }\end{array}$ & $\begin{array}{c}\text { Nilai } x \\
(\mu \mathrm{g} / \mathrm{ml})\end{array}$ & $\begin{array}{c}\text { Polifenol } \\
\text { total (\%) }\end{array}$ \\
\hline & 0,087 & 0 & 2,00 & 2,00 \\
$\mathrm{y}=0,077 \mathrm{x}-0,069$ & 0,092 & 0 & 2,07 & 2,07 \\
$\mathrm{R}^{2}=0,996$ & 0,109 & 0 & 2,29 & 2,29 \\
& & & Rata-rata & 2,12 \\
& & & SD & 0,151 \\
\hline
\end{tabular}

Berdasarkan hasil perhitungan kadar polifenol total ekstrak etanol daun sambung nyawa dengan pelarut etanol $70 \%$ diperoleh kadar polifenol total sebesar 2,12 \% b/b GAE Penelitian sebelumnya yang dilakukan oleh Afandi et al (21) memperoleh nilai polifenol total ekstrak etanol daun sambung nyawa sebesar 70,70 $\pm 2,58 \mathrm{mg} \mathrm{GAE} / \mathrm{g}$, dimana hasil ini menunujukkan nilainya total polifenol lebih besar pada pelarut etanol daripada pada pelarut air, namun lebih sedikit jika dibandingkan dengan pelarut metanol. Selanjutnya penelitian yang dilakukan oleh Algariri et al (22) kadar polifenol total ekstrak etanol $75 \%$ daun sambung nyawa sebesar 54,58 mg GAE/g. Metabolit polifenol memiliki sifat antioksidan yang cukup besar tetapi pada suhu tinggi mereka dapat terdegradasi menjadi senyawa lain dengan potensi antioksidan yang tidak signifikan (23).

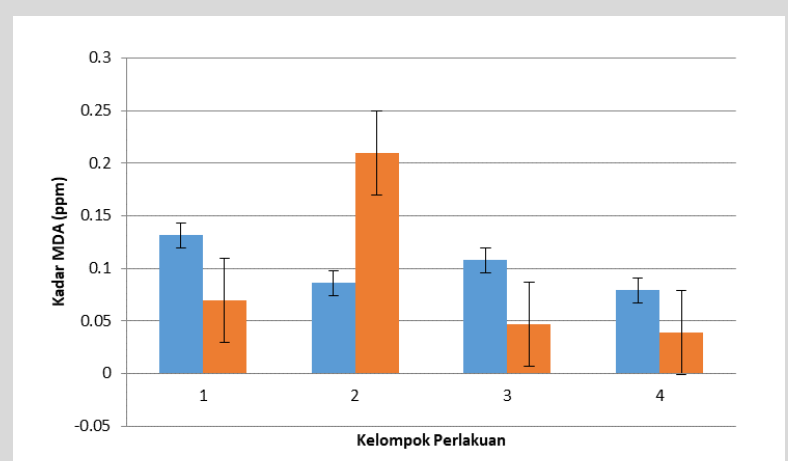

Gambar 1. Grafik rata-rata kadar MDA darah

\section{Keterangan:}

Kelompok 1 = Kontrol sehat (tanpa perlakuan)

Kelompok $2=$ Kontrol negatif (diberikan penginduksi CCI4)

Kelompok 3 = Perlakuan (diberikan ekstrak $150 \mathrm{mg} / \mathrm{kgBB}+$ penginduksi $\mathrm{CCl} 4$ )

Kelompok 4 = Perlakuan (diberikan ekstrak $300 \mathrm{mg} / \mathrm{kgBB}+$ penginduksi $\mathrm{CCl} 4$ )

$(*)$ Menunjukkan perbedaan signifikan terhadap kelompok kontrol negatif $(p<0,05)$

Pemeriksaan rata-rata kadar MDA darah pada tikus Wistar yang diberikan ekstrak etanol daun sambung nyawa terenkapsulasi dengan penginduksi $\mathrm{CCl}_{4}$ dan perbandingannya dengan kontrol negative (Gambar 1). Hasil pengukuran kadar MDA darah tikus Wistar diperoleh hasil bahwa ektrak etanol daun sambung nyawa mampu menurunkan peroksidasi lipid malondialdehida. Hasil uji menunjukkan bahwa kadar MDA darah pada kelompok 2 lebih tinggi dibandingkan dengan kelompok perlakuan yang diberikan ekstrak etanol daun sambung nyawa. Pada uji Post Hoc Tukey hasil menunjukkan bahwa kadar MDA darah pada kelompok 2 berbeda sangat signifikan dengan kelompok perlakuan pada kelompok 3 dan 4 dimana $p<0,05$. Sambung nyawa memiliki senyawa flavonoid yang merupakan antioksidan non-enzimatis. Tingginya kadar radikal bebas dalam tubuh dapat ditunjukkan oleh rendahnya aktivitas enzim antioksidan dan tingginya kadar malondialdehid (MDA) dalam plasma (24). Ekstrak daun sambung nyawa memiliki efek positif pada radikal bebas dan chelating besi (25).

\section{KESIMPULAN}

Kesimpulannya bahwa ekstrak etanol daun sambung nyawa (Gynura procumbens) terenkapsulasi maltodextrin mampu mencegah peningkatan aktivitas peroksidasi lipid melondialdehida pada dosis $150 \mathrm{mg} / \mathrm{kgBB}$ dan $300 \mathrm{mg} / \mathrm{kgBB}$ pada tikus Wistar jantan yang diinduksi $\mathrm{CCl}_{4}$.

\section{UCAPAN TERIMA KASIH}

Penulis mengucapkan terima kasih kepada pihak BUDI-DN LPDP 2016 atas supportnya dalam hal pendanaan. Penulis juga berterima kasih kepada Fakultas Farmasi Universitas Hasanuddin atas dukungan moril dan sarana selama penulis melakukan penelitian.

\section{DAFTAR PUSTAKA}

1. Mir, A., Anjum, F., Riaz, N., Iqbal, H., Wahedi, H.M., Khattak, J.Z.K., Khan, M.A., and Malik, S.A. Carbon Tetrachloride $\left(\mathrm{CCl}_{4}\right)$-Induced Hepatotoxicity in Rats: Curative Role of Solanum nigrum. Journal of Medicinal Plants Research. 2010;4(23)

2. Ozturk, F., Ucar, M., Ozturk, I.C., Vardi, N., and Batcioglu, K. Carbon Tetrachloride-Induced Nephrotoxicity and Protective Effect of Betaine in Sprage-Dawley Rats. Urology. 2003;62(2)

3. Tan, H.L., Chan, K.G., Pusparajah, P., Lee, L.H., and Goh, B.H. Gynura procumbens: An Overview of the Biological Activities. Frontiers in Pharmacology. 20106;7(52).

4. Fadli, M.Y. Artikel review, Benefits of Sambung Nyawa (Gynura procumbens) Subtance as Anticancer. Journal Majority. 2015; 4(5).

5. Utami, P., and Puspaningtyas, D.E. The Miracle of Herbs. Pt Agromedia Pustaka: Jakarta Selatan. 2013.

6. Kim, J., Lee, C.W., Kim, E.K., Lee, S.J., Park, N.H., Kim, H.S., Kim, H.K., Char, K., Jang, Y.P., and Kim, J.W. Inhibition Effect of Gynura procumbens Extract on UV-B-Induced Matrix-Mettalloproteinase Expression in Human Dermal Fibrobalsts. Journal of Ethnopharmacology. 2011;137(1).

7. Da'i, M., Ratnaningrum, A.D., Wahyuni, A.S., Melannisa R., and Trisharyanti, I.D.K. Radical Scavenging Activity DPPH (1,1-diphenyl-2pikrilhidrazyl) Assay of Ethanol Extract of Elephantopus schaber L., Ocimum basillicum L. Forma citratum Back, Graptophylum pictum Griff, and Gynura procumbens Merr. Leaves and Determination of Concentration Total Phenolic. Pharmacon. 2012;13(2).

8. Li, X.J., Mu, Y.M., Li, T.T., Yang, Y.L., Zhang, M.T., Li, Y.S., Zhang, W.K., Tang H.B., and Shang, H.C. Gynura procumbens Reverses Acute and Chronic Ethanol-Induced Liver Steatosis throught MAPK/SREBP-Ic-Dependent and Independent. Journal of Agricultural and Food Chemistry. 2015;63(38).

9. Madene, A., Jacquot, M., Scher, J., and Desobry, S. Flavour encapsulation and controlled release: A review. International Journal of Food Science and Tehnology. 2006; 41.

10. Man, Y. B. C., Irwandi, J., and Abdullah, W. J. W. Effect of different types of maltodextrin and drying methods on physico-chemical and sensory properties of encapsulated durian flavour. Journal of the Science of Food and Agriculture. 1999;79(8).

11. Peranginangin, J.M. Hepatoprotective Effect Of Ethanol Extract Of Dewa Leaf (Gynura Procumbens (Lour) Merr) At Mouse Induceed By Parasetamol. Biomedika : jurnal ilmiah biologi dan kesehatan. Fakultas Farmasi Universitas Setia Budi. Surakarta. 2010;3.

12. Harborne, J.B. Metode Fitokimia Penuntun Cara Modern Menganalisa Tumbuhan, Terbitan Kedua. Institut Teknologi Bandung: Bandung. 1987.

13. Hairon, H., Sabtu, R., Talib, N. A., Awang, M. A., Aziz, R., Suan, C. L., and Taher, Z. M. Comference Proceeding. 2016.

14. Bakhtra, D. D. A., Jubahar, J., and Yusdi, E. Uji Aktivitas Fraksi dari Ekstrak Daun Sambung Nyawa (Gynura procumbens Lour) Merr.) terhadap Bakteri Shigella dysenteriae. Jurnal Farmasi Higae. 2018;10(1)

15. Sangi, M., Runtuwene, M. R. J, Simbala, H. E. I., and Makang, V. M. A Analisis fitokimia tumbuhan obat di Kabupaten Minahasa Utara. Chem. Prog. 2008;1(1). 
16. Robinson, T. Kandungan Organik Tumbuhan Tinggi. Terjemahan Kosasih Padwinata. Institut Teknologi Bandung: Bandung. 1995.

17. Faradisa, M. Uji Efektivitas Anti Mikroba Senyawa Saponin dari Tanaman Belimbing Wuluh (Averrhoa bilimbi Linn.) UIN Malang. Malang. 2008.

18. Saifudin, A. Senyawa Alam metabolit sekunder Teori, konsep, dan teknik pemurnian Edisi 1. Deepublish: Yogyakarta. 2014.

19. Chang, C.C., Yang, M.H., Wen, H.M., and Chern, J.C. Estimaton of Total Flavonoid content in Propolis by Two Complementary Colometric Methods. Journal of Food and Drug Analysis. 2002;10(3)

20. Zirconia, A., Kurniasih, N., dan Amalia, V. Identifikasi Senyawa Flavonoid dari Daun Kembang Bulan (Tithonia diversifolia) dengan Metode Pereaksi Geser. Al Kimiya. 2015;2(1)

21. Afandi, A., Zulkiffli, H. M., Sadikun, A., and Ismail, S. Antioxidant Properties of Gynura procumbens Extracts and Their Inhibitiry Effect on Two Mayor Human Recombinant Cytochrome P450S Using A High
Throughput Luminescence Assay. Asian Journal of Pharmaceutical and Clinical Research.20104;7(5)

22. Algariri, K., Meng, K. Y., Atangwho, I. J., Asmawi, M. Z., Sadikun, A., Murugaiyah, V., and Ismail, N. Hypoglycemic and Anti-hyperglycemic Study of Gynura procumbens Leaf Extracts. Asian Pac J Top Biomed. 2013;3(5)

23. Akowuah, G. A., Mariam, A., and Chin, J. H. The Effect of Extraction Temperature on Total Phenols and Antioxidant Activity of Gynura procumbens Leaf. Research Article. 2009;6(17).

24. Winarsi, H. Antioksidan alami dan radiakl bebas. Kanisius: Yogyakarta. 2007.

25. Puangpronpitag, D., Chaichanadee, S., Naowaratwattana, W., Sittiwet, C., Thammasarn, K., Luerang, A., and Kaewseejan, N. Evaluation of nutritional value and antioksidative properties of the medicinal plant Gynura procumbens extract. Asian Journal of plant sciences. 2010;9(3). 